\title{
Biotechnologies to Bridge the Schism in the Bioeconomy
}

\author{
Jim Philp
}

check for

updates

Citation: Philp, J. Biotechnologies to Bridge the Schism in the Bioeconomy. Energies 2021, 14, 8393. https:/ / doi.org/10.3390/en14248393

Academic Editors: Stelios Rozakis and Luka Juvančič

Received: 24 October 2021

Accepted: 9 December 2021

Published: 13 December 2021

Publisher's Note: MDPI stays neutral with regard to jurisdictional claims in published maps and institutional affiliations.

Copyright: (C) 2021 by the author. Licensee MDPI, Basel, Switzerland. This article is an open access article distributed under the terms and conditions of the Creative Commons Attribution (CC BY) license (https:/ / creativecommons.org/licenses/by/ $4.0 /)$.
Directorate for Science, Technology and Innovation, The Organisation for Economic Cooperation and Development, 75016 Paris, France; James.PHILP@oecd.org

\begin{abstract}
Schism is the new normal for the bioeconomy concept. Since its proliferation in governments, the concept has been adapted to fit national or regional exigencies. Earlier this century the knowledge-based bioeconomy (KBBE) in Europe was seen as a technical and knowledge fix in the evolving sustainability landscape. At the OECD, the concept was further honed by imagining a future where biotechnologies contribute significantly to economic growth and development. Countries started to make national bioeconomy strategies. Some countries have diverged and made the bioeconomy both much larger and more general, involving a wide variety of sectors, such as industry, energy, healthcare, agriculture, aquaculture, forestry and fishing. Whatever the approach, what seems to be consistent is the need to reconcile environmental, social and economic sustainability. This paper attempts to establish one schism that could have ramifications for the future development of the bioeconomy. Some countries, including some of the largest economies but not exclusively so, are clearly following a biotechnology model, whereas others are clearly not. In the wake of the COVID-19 pandemic, biotechnologies offer outstanding potential in healthcare, although this sector is by no means included in all bioeconomy strategies. The paper also attempts to clarify how biotechnologies can address the grand challenges and the United Nations Sustainable Development Goals. The communities of scientists seem to have no difficulty with this, but citizens and governments find it more difficult. In fact, some biotechnologies are already well established, whereas others are emerging and more controversial.
\end{abstract}

Keywords: biotechnology; synthetic biology; bioeconomy; sustainability; grand challenges

\section{Introduction}

The bioeconomy concept is decades old, but the story for this paper starts with a landmark publication from the OECD [1], where the science and technology of the bioeconomy was discussed in terms of public policy, thereby putting the bioeconomy on a political and economic footing. It described the bioeconomy as "the set of economic activities in which biotechnology contributes centrally to primary production and industry, especially where the advanced life sciences are applied to the conversion of biomass into materials, chemicals and fuels". This cemented the idea that biotechnology is a separate discipline from fundamental research in the life sciences that can generate economic activity and added value. Added value is an important component as it can be also applied to the circular economy concept [2], and there have been efforts to link the bioeconomy and circular economy [3]. This is especially so if "waste" materials such as agricultural and forestry residues and waste industrial gases can be converted through biotechnology into useful products and services.

Another plank of biotechnology in the bioeconomy is the inextricable connection to sustainability. All national bioeconomy strategies connect to sustainability, whether they emphasise biotechnology or not. The European Knowledge-Based Bio-Economy (KBBE) elaborated a bioeconomy view that reconciles the conundrum of environmental and economic sustainability [4].

Running through this paper is the concept of 'grand challenges': the major dilemmas that humanity faces, some of such gravity that they are existential for our species. These in- 
clude food security, energy security, resource depletion, deforestation, biodiversity threats, even soil security. Overarching all of these is, of course, climate change [5]. Not only are these issues existential, but, troublingly, they are particularly difficult to address as they interact with each other in what has been termed a "grand challenges ecosystem" [6]. In other words, attempting to address one of these can create problems in another. For example, a rising human population demands reducing food waste and growing more food. Land intensification and extensification might result in increasing soil exhaustion. Such examples are many, and for policymakers this creates unprecedented challenges. As grand challenges interact and overlap, then policymakers have the unenviable task of attempting to design policy that minimises the possibilities of unintended, and unwanted, consequences.

\section{Typologies of the Bioeconomy}

As the bioeconomy concept has burgeoned during the last decade, other interpretations have been described that are not necessarily independent of biotechnology, but at least significantly de-emphasise it. Various authors have compared and contrasted the increasing number of national bioeconomy strategies as the concept has gained acceptance since the first elaborations in the second decade of this century. During the last decade, many differing views on what constitutes a definition of a bioeconomy have arisen. A single, harmonised definition has the simplistic beauty that it can then be used to measure and compare the contributions of the bioeconomy to the economy overall. Its crystallisation now seems evanescent, as definitions have often arisen in response to the priorities of an individual country [7].

More interesting is to examine how bioeconomy narratives have developed. At least three papers recognise similar extrapolations of the concept [8-10]. For clarity, the extrapolation of three narratives described by Vivien et al. illustrates this development [10]. To précis: Type I considers the limits of the biosphere; Type II is a science-based bioeconomy; and Type III is a biomass-based bioeconomy. Type II does not hold all of the answers; technology fixes never do [11].

The basis for the focus on a science-based bioeconomy is an argument that biotechnologies partially address all three of these narratives. Vivien et al. also noted that Type II and Type III may merge, and the argument could be made that they already are. This paper would like to take the argument further by positing that biotechnologies can also partially address the limits of the biosphere (Type I) [10]. The justification for stating this can be explained in unsustainability. It is entirely foreseeable that the increasing use of biomass may lead to over-exploitation of natural resources and unintended consequences such as increased illegal logging, soil degradation, decreased biodiversity and international disputes. In this way, attempting to implement a Type I bioeconomy via the biomass resource (Type III) could lead to an unsustainable bioeconomy. Rather, this paper argues that biotechnologies and other technologies (Type II) have many and varied roles to play in advancing the sustainable exploitation of biomass and waste materials (Type III) to stay within planetary boundaries (Type I).

\section{How Are Biotechnology and Synthetic Biology Captured in National Bioeconomy Strategies?}

A presumption at the start of this work was that the interpretation of bioeconomy had changed since the OECD work that in 2009 emphasised biotechnology as an enabler of economic activity. All bioeconomy strategies were written in terms of future sustainability. Indeed, Marvik and Philp stated that the fundamental justification for public intervention in the bioeconomy is increased sustainability [12]. However, few nations include biotechnology and synthetic biology in the bioeconomy, which is likely to cause an uneven economic impact of the bioeconomy. Moreover, this will lead to difficulties in comparing and contrasting bioeconomies across different countries.

In Europe, a large number of biotechnology companies are in the human health sector, but the European Union vision of the bioeconomy specifically excludes human health or medicine $[13,14]$. There has been what looks like a significant retrenchment from 
biotechnology in the European Union between 2012 and 2018. In the main text, excluding footnotes and bibliography, the word "biotechnology" appears only three times in the updated EU bioeconomy strategy. Curiously, though, the 2018 update also states that "biotechnology is at the heart of bio-based processes", while specifically excluding "health biotechnology and biological medicines" from the bioeconomy definition.

Some other countries also exclude the human health heartland of biotechnology from their bioeconomy strategies. The Italian update (2019) refers to human health in terms of agriculture and food, not through medicines [15]. The French 2018-2020 bioeconomy Action Plan made no reference to medicine or pharmaceuticals [16].

However, other bioeconomy strategies make specific reference to human health in terms of health biotechnologies. For example, an unofficial translation of the Japanese bioeconomy strategy (2020) delineated " ... industries related to biopharmaceuticals, regenerative medicine, cell therapy, and gene therapy" [17]. The United Kingdom strategy (2018) refers to manufacturing the " ... medicines of the future and making existing ones more efficiently" [18]. The United States Bioeconomy Blueprint (2012) made explicit reference to the impacts of the bioeconomy in the biomedical sector: biomedical innovation is a major strength of the US research enterprise. The US approach is reinforced by a more recent report [19], where a recommended definition of bioeconomy placed biotechnology and economic activity at the centre of its meaning, along with the convergence that has been seen with digital technologies:

"The U.S. bioeconomy is economic activity that is driven by research and innovation in the life sciences and biotechnology, and that is enabled by technological advances in engineering and in computing and information sciences."

Unsurprisingly, then, one of the six segments of the bioeconomy captured in this report is "biopharmaceuticals and biologics and other pharmaceuticals". Also of high significance is that another segment is "genetically modified crops/products", which is absent from the scope of European bioeconomy strategies. Whereas genetically modified (GM) crops account for approximately half of all crop sales in the United States, commercial cultivation of GM crops is currently banned in a number of EU countries [7].

Germany is an interesting case. The national bioeconomy strategy of 2013 and the update in 2020 were very broad-based. The 2020 summary document stated that the Federal Government of Germany defines the bioeconomy as "the production, exploitation and use of biological resources, processes and systems to provide products, processes and services across all economic sectors within the framework of a future-oriented economy" [20]. This six-page summary subsequently is somewhat sector neutral, and there is no mention of biotechnology, medicine or pharmaceuticals. There is, however some emphasis on biogenic resources and biogenic raw materials

The 2020 summary was published by the German Federal Ministry of Education and Research (BMBF). The same Ministry appointed the High-Tech Forum in 2019, which published a far-reaching discussion paper on the convergence of biotechnologies with information technologies [21]. The paper referred to The High-Tech Strategy of 2025 (HTS), which "pursues the overarching goal of contributing to sustainable solutions to major social challenges". Among others, the report stated that the SDG goal on health and wellbeing is paramount. This apparent contradiction between the bioeconomy strategy and the high-tech strategy in Germany is difficult to explain. However, it does show that Germany values this convergence as a source of future economic activity. Moreover, it recognises it in medicine, whereas the bioeconomy strategy does not.

This narrative could be continued by including other countries and their national strategies. It might suffice to say that there is evidence of a significant schism in the approach to national bioeconomy strategies. It would seem that the world's largest economies are adopting a biotechnology-based approach. Another approach could be to examine a word analysis in the small number of synthetic biology national roadmaps (Table 1). 
Table 1. Word analysis of synthetic biology roadmaps. The words are loosely grouped into three groups, the first being bioeconomy and commerce-based, the second being engineering and industrybased, and the third being science and research-based. The numbers represent the number of times each keyword appears per page.

\begin{tabular}{cccccc}
\hline Keyword & Australia & France & Finland & United Kingdom & European Union \\
\hline Sustainable & 0.081 & 0.000 & 1.500 & 0.316 & 0.139 \\
\hline Bioeconomy & 0.035 & 0.000 & 2.222 & 0.368 & 0.000 \\
\hline Business & 0.064 & 0.250 & 0.639 & 1.263 & 0.070 \\
\hline Commercialisation & 0.099 & 0.000 & 0.111 & 0.368 & 0.046 \\
\hline Investment(s) & 0.186 & 0.458 & 0.305 & 1.947 & 0.209 \\
\hline Total & 0.384 & 0.708 & 3.277 & 3.946 & 0.325 \\
\hline Biorefinery & 0.023 & 0.000 & 0.111 & 0.000 & 0.000 \\
\hline Engineering & 1.442 & 0.208 & 0.444 & 2.421 & 1.442 \\
\hline Industry & 0.680 & 0.208 & 1.833 & 1.684 & 0.442 \\
\hline Manufacturing & 0.157 & 0.042 & 0.139 & 0.421 & 0.046 \\
\hline Total & 2.302 & 0.458 & 2.527 & 4.526 & 1.930 \\
\hline Innovation(s) & 0.546 & 0.166 & 0.333 & 3.316 & 0.465 \\
\hline Education & 0.302 & 0.042 & 0.389 & 0.632 & 0.419 \\
\hline Science & 1.064 & 0.708 & 0.833 & 4.369 & 2.395 \\
\hline Research & 2.140 & 1.750 & 2.166 & 7.210 & 3.930 \\
\hline Total & 8.104 & 2.666 & 3.721 & 15.527 & 14.418 \\
\hline
\end{tabular}

There may be various ways to interpret this table, but the interpretations could be misguided. Only a few of the more obvious observations are made here. Firstly, the synthetic biology roadmap for France does not make mention of the words sustainable or bioeconomy. This seems surprising as France is home to a large proportion of European biotechnology firms, with over 2000 in 2018 [22], but makes sense as the French bioeconomy strategy excludes human health biotechnology.

Secondly, three of these synthetic biology roadmaps make no mention of biorefineries, the physical embodiment of the bioeconomy. France has arguably the most successful integrated biorefinery in the world, but biorefineries do not feature in its synthetic biology roadmap [23].

Thirdly, some countries appear to be framing synthetic biology more in science and research than in engineering and industry. Again, over-interpretation is to be avoided, but too large an emphasis on the science and research may discourage private sector investment, thus lowering the return on public investment for a country, with the danger of commercialisation in a different country. This has been an argument in the past, at least at the anecdotal level, about Europe generally, i.e., that the commercial benefits of European R\&D occur outside Europe.

For biotechnologies to take a major place in a sustainable future, there has to be evidence of economic relevance. To many outside biotechnology, the findings of Carlson would be surprising [24]. He estimated a substantial contribution of biotechnology to the overall US economy-more than $2 \%$ to gross domestic product. This was likely to be almost one trillion dollars [19].

Carlson revealed the difficulty to (economically) distinguish identical bio-based and fossil-based chemicals due to the lack of a North American Industrial Classification System (NAICS) code for the former products. Ronzon et al. encountered similar problems with the European NACE (Nomenclature Statistique des Activités Économiques dans la Communauté Européenne) classification [25]. Little wonder, then, that Carlson con- 
cluded that: "It is well past time for governments around the world to collaborate in developing a standardized and comprehensive understanding of the role of biology in their economies" [24].

A study by the McKinsey Global Institute examined the economic contributions of the "bio revolution" in some detail [26]. Figure 1 is an overarching chart from the report. Figures are trillions of US dollars.

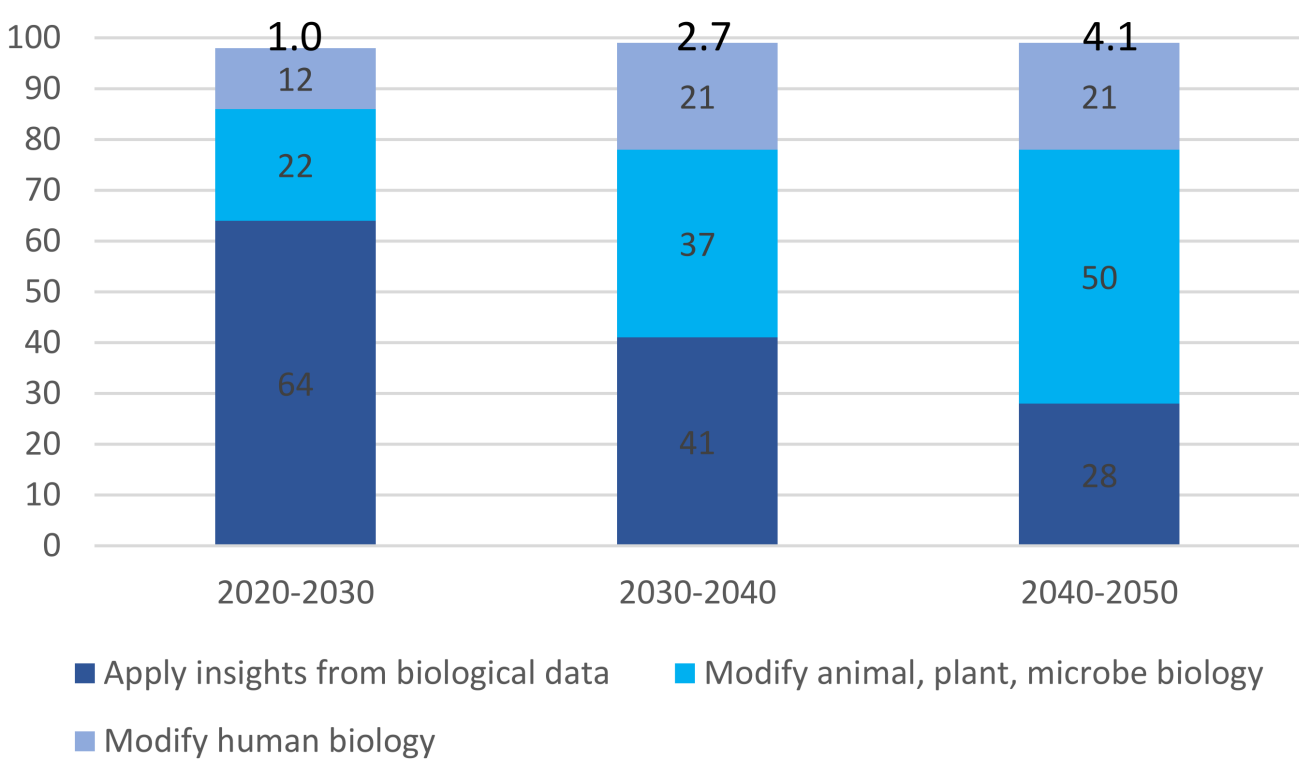

Figure 1. Estimated economic impact of the bio revolution in the near, medium and long term. Sized applications by technology platform (partial estimate). Adapted from [26].

\section{Qualifying Comments}

Interpretation of the word analyses should be viewed with caution beyond the very obvious. Three general comments are made here.

1. The taxonomy of bioeconomy is ongoing and is as yet incomplete. In particular some countries and the European Union are not yet integrating biotechnology into bioeconomy. The result could be a "two-speed" bioeconomy, with some countries missing out on economic, environmental and social opportunities. At the extreme end, the United Kingdom and the United States have placed great emphasis on synthetic biology in the bioeconomy, and have established sophisticated publicly funded infrastructures.

2. Such unaligned taxonomies will make difficulties for governments to compare and contrast the impacts of the bioeconomy strategies. Theoretically, this could negatively impact international trade. As Carlson discovered, even in the United States there is no official mechanism to measure the economic impact of the biotechnology industry. Undoubtedly this is the case in other countries [24].

3. The magnitude of the McKinsey Global Institute bio-revolution estimates suggests that countries that exclude biotechnologies from their bioeconomy strategies will see proportionately smaller impacts on their national economies than those that do [26]. It is perhaps telling that the Canada's unofficial strategy proposed to use the European Union bioeconomy definition but will "rely on biotechnology as a competitive advantage" [27]. If the economic impact of the McKinsey bio-revolution is accurate, then over $70 \%$ of the annual potential direct economic impact in 2030-2040 will be distributed between "human health and performance", and "agriculture, aquaculture, and food". As of today, there is a high risk that Europe will miss much of this windfall. 


\section{Biotechnology, Synthetic Biology and the Bioeconomy}

"Advances in synthetic biology have the potential to develop new products, materials and services that could contribute to the 2030 United Nations Sustainable Development Goals. Support for synthetic biology initiatives in developing countries is needed to ensure that these benefits are open to all." [28]

This section constitutes the second half of the paper. It is not meant to be exhaustive in its treatment of biotechnologies in the bioeconomy. A theme is how one action to address grand challenges can have negative consequences elsewhere, and how biotechnologies may help to solve these interacting puzzles. This is often evident at the level of SDGs: addressing one SDG can affect another. This complexity is something that biotechnologies should be good at addressing as the great variety of nature can be brought into play. This variety is due to increase dramatically as a result of sequencing initiatives such as the Earth Biogenome Project [29].

\subsection{Enabling the Bioeconomy}

It was less than three decades ago that Frost and Lievense discussed biotechnological routes to aromatic compounds in reference to "environmental considerations and the scarcity of petroleum" [30]. Metabolic engineering enabled biotechnological routes to entirely unnatural chemicals [31]. Many of today's petrochemicals do not exist in nature. The first claimed success of making a wholly unnatural chemical biologically was 1,4-butanediol by Yim et al. [32].

There have been hundreds if not thousands of metabolic engineering research papers where a bio-based chemical has been made in the research laboratory. Figure 2 illustrates some of the possibilities for replacing the oil barrel. It should be stressed that most of these successes have been in the laboratory. There has only been a tiny number of commercialisations, mainly due to difficulty in scale up to market.

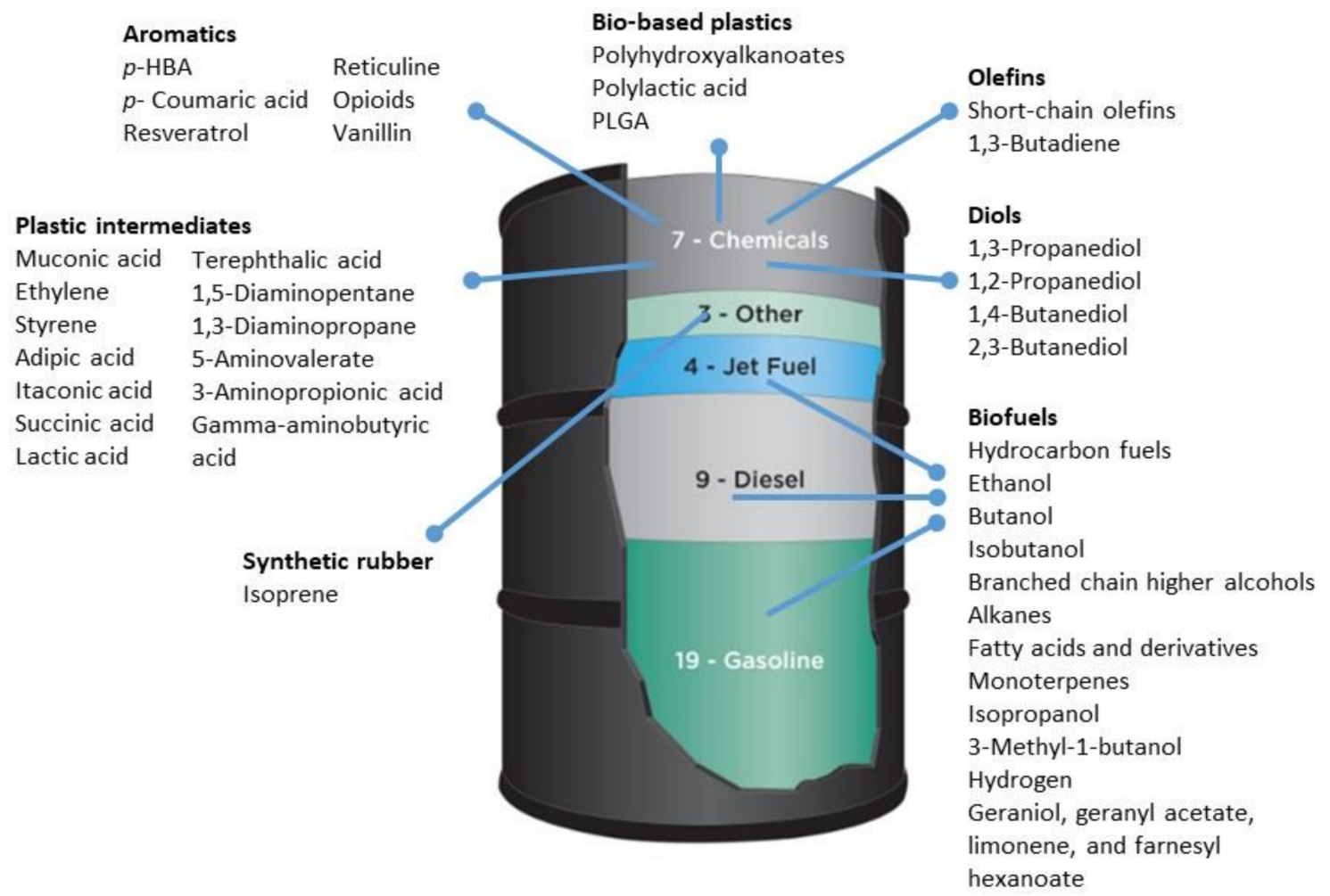

Figure 2. Replacing the oil barrel. 
Synthetic biology is considered to be the next phase that increases the success rate of commercialisation of bio-based chemicals, materials, textiles, plastics, fuels and biopharmaceuticals [33]. With the emergence of the biofoundry concept, it has become clear that the number of successes at small scale has accelerated. There are at least two lines of evidence for this.

1. To test the technology, the MIT-Broad Institute biofoundry was tasked to build organisms to produce 10 molecules in 3 months. The biofoundry succeeded with 6 out of 10 targets [34].

2. Over a period of 85 days, the Manchester (UK) biofoundry was able to produce 17 potential material monomers and key intermediates, in some cases with industrialscale titres for E. coli fermentations [35].

In the chain from idea to industrial production, it may be that the biofoundry is the missing link (Figure 3) that at last improves reproducibility and reliability in biotechnology and the life sciences [36]. Further digitalisation of biology will advance the field further in the near future. Overcoming some of the limitations of biology in industrial processes will require workflows that split biochemical conversion from chemical catalysis, allied to the automation of synthetic chemistry [37,38]. Eventually, robotically built worklists and machine learning algorithms will fully automate biomanufacturing in the absence of human intervention [39].
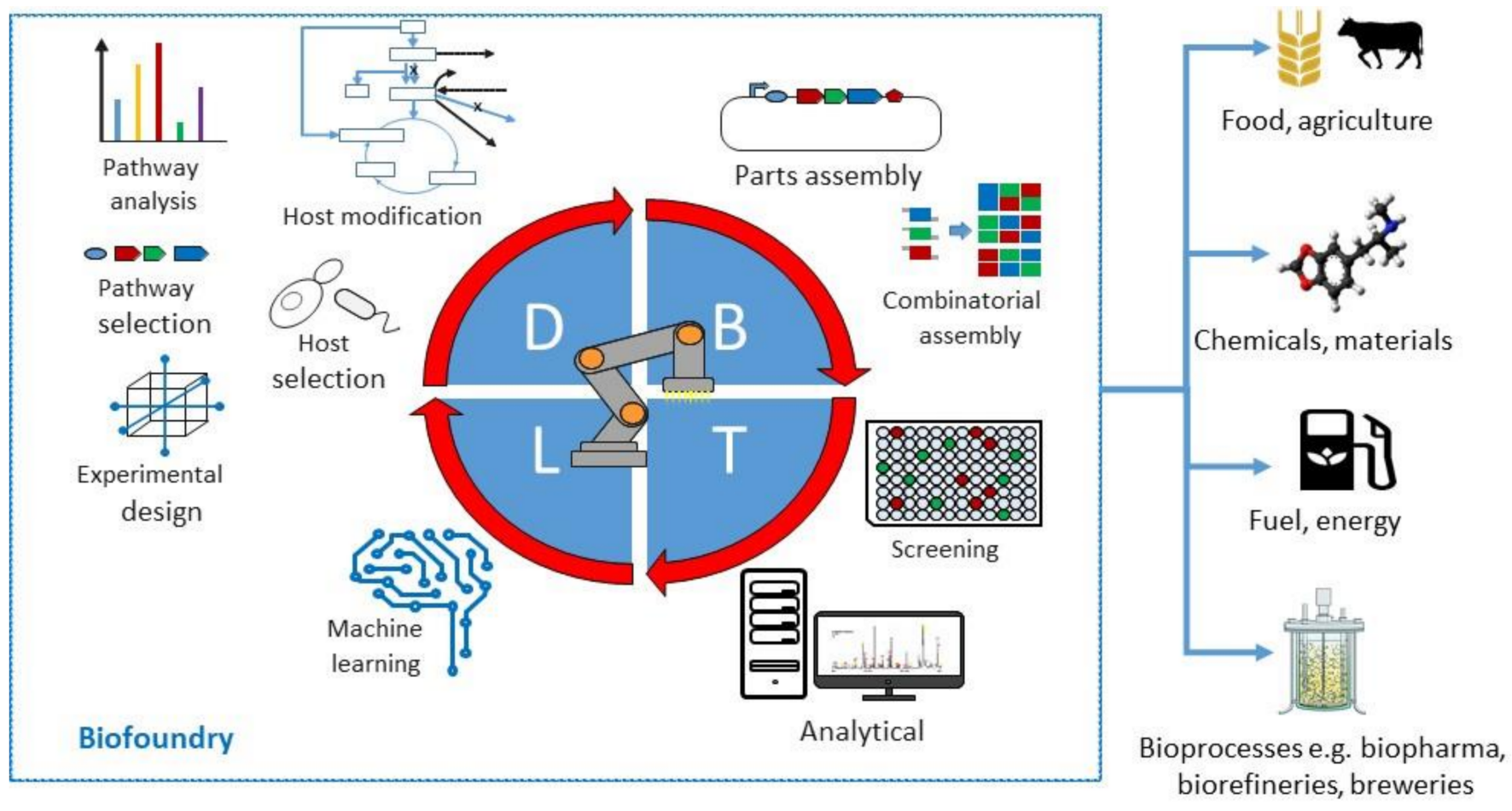

Figure 3. The biofoundry and the design-build-test-learn (DBTL) concept as a platform for manufacturing across a range of sectors. Adapted from [36].

\subsubsection{Are Bio-Based Chemicals Sustainable?}

The literature has sometimes found bio-based chemicals to be more sustainable than their fossil equivalents. Figure 4 (adapted from [40]) below points to some issues. The authors found that the bio-based materials make significant savings on average on nonrenewable energy and $\mathrm{CO}_{2}$ emissions per $\mathrm{kg}$ material compared to fossil counterparts. However, the error bars adumbrate uncertainties between different studies. 

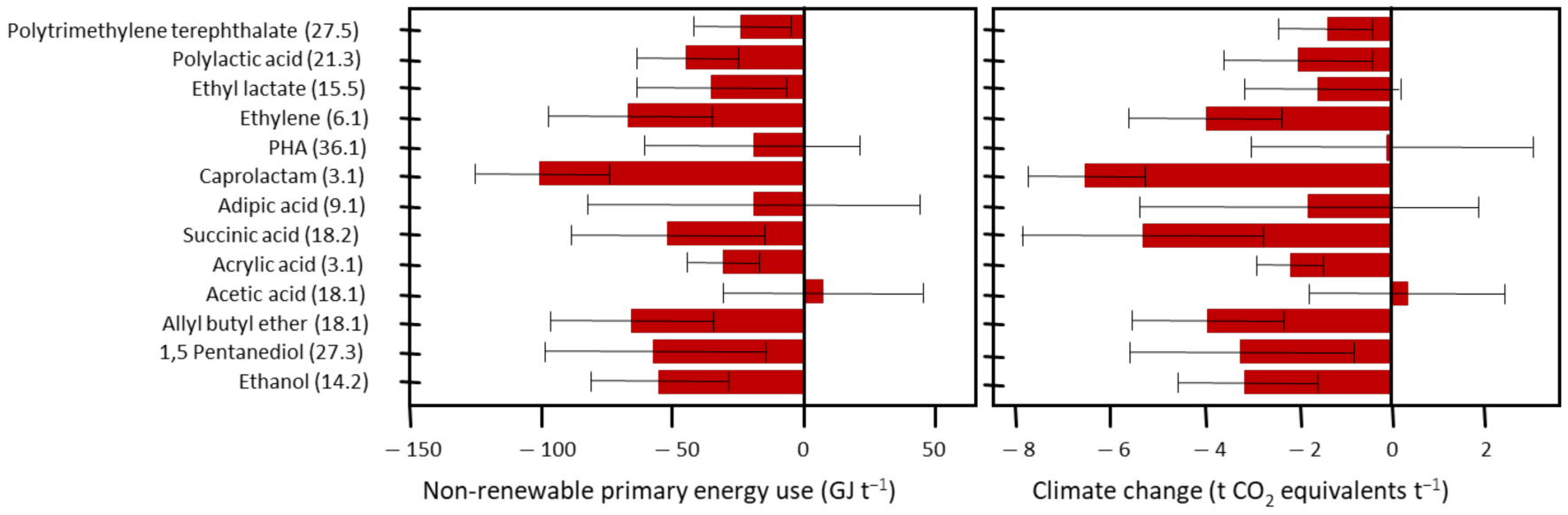

Figure 4. Average non-renewable primary energy use and GHG emissions of bio-based chemicals in comparison to conventional chemicals [40]. Numbers in parentheses indicate the sample size for the bio-based and conventional chemicals, respectively.

LCA does not take account of economic and social sustainability, focusing on environmental aspects. Many of the potential criteria are hard to measure. Social criteria, such as land rights and labour conditions, are also controversial and make it difficult to reach international consensus [41].

\subsubsection{Waste Gas Fermentation: Relief for Land Use}

The microbial fermentation of waste industrial gases to useful products is becoming reality [42-44]. It remains for synthetic biology and metabolic engineering to expand the product spectrum to fuels and commodity chemicals [45]. The rational design of the synthetic biology approach is appropriate to such microbes.

There are various ways that fermenting waste gases of products contributes to sustainability. It is one of the emerging technologies of carbon capture and utilisation (CCU), effectively a value-adding strategy compared to carbon capture and storage (CCS) [46]. A cradle-to-grave life cycle analysis (LCA) for the production of ethanol by gas fermentation estimated a $67 \%$ GHG reduction using steelmaking off-gases compared to conventional fossil gasoline [47]. Perhaps its greatest contribution will be that it relieves pressure on land use, thus ameliorating concerns over indirect land use change (ILUC) [48]. When deployable widely at scale, policymakers would have to include measures to prevent an unintended consequence- - using these waste gases to make value-added products could easily disincentivise waste reduction.

\subsection{Greening the Bioeconomy: Biotechnology in Agriculture for the Grand Challenges}

COP26 demonstrated the need to phase out fossil resources. Thus, more chemicals, fuels, materials, and electricity will be derived from biomass, increasing competition for land [49]. Long overlooked by policymakers, soil is the ultimate resource: around $95 \%$ of all food comes from cropland [50]. By 2050, 50-70\% more food will need to be produced, often during drought and with damaged soil [51,52]. This points to a major conundrum for the bioeconomy-conflicting needs of agriculture and industry [53]. It is not known how much industrial production can come from biomass. Moreover, marine and terrestrial biomass play essential roles in biodiversity and conservation, and industrial needs must reflect this necessity. Food is not just about quantity but quality and diversity. Biotechnology can also offer benefits in terms of diversity of sources-as long as the fundamentals of quality and quantity are also acted upon. 


\subsubsection{Water Use Efficiency in Plants}

Globally, 70\% of all freshwater use is for agriculture [54]. Knowledge of the physiology and genetics of plant processes and traits can improve the water use efficiency of crops, and is expanding rapidly [55]. The Canadian company Performance Plants is the first company to make use of native genetic technology that allows plants to grow normally and produce high seed yields with significantly less water. Another high interest area of research is microbiomes in the bioeconomy and the circular economy. Understanding plant microbiomes may lead to increasing crop yields under stressed environmental conditions [56].

\subsubsection{Food Security Threats from Crop Diseases}

Crop loss through pests and disease is a significant factor in food security. Banana makes an interesting case. Over 100 million Africans rely on banana as a staple of their diet. However, banana is attacked by many pests. For example, the bacterial disease Xanthomonas wilt (BXW) is capable of destroying an entire plantation. Development of improved varieties of banana is fundamental in order to tackle disease [57], whilst maintaining or improving nutritional value. A transgenic banana has demonstrated total resistance to BXW by introducing two resistance genes from sweet pepper [58].

\subsubsection{Improving Yields of Oil Palms}

Some $45 \%$ of edible oil worldwide come from oil palm, but it competes for dwindling rainforest reserves [6]. The oil palm genome sequence has been published [59]. It has enabled the identification of genes for important commercial traits. Regulating the Shell gene can increase palm oil yield by nearly one-third. Identifying a high-yielding oil palm plantlet can take six years. However, the genetic marker for the Shell gene can recognise highest oil yield forms as early as in the nursery [60].

\subsubsection{Resolving Contradictions of Mineral Fertilizers}

Supplying sufficient nitrogen to cereal crops is a major challenge in agriculture [61]. Wheat is the second-most consumed food crop in the developing world [62]. High yields have been maintained using mineral fertilizers, but intensification has been unsustainable. They contribute to water eutrophication and account for high emissions. Fertilizer production requires $3-5 \%$ of natural gas production [63].

Several long-term efforts are ongoing in a tantalising research area-creating cereal crop plants that make their own fertilizer by atmospheric nitrogen fixation [64], holding out hopes to decouple agriculture from fossil fuels. Using synthetic biology, full nitrogen fixation in cereals is still in the future [65]. However, partial nitrogen fixation may be available within the decade [66]. There is also potential for soil microbiomes to be used as bio-based fertilizers to ameliorate nitrogen leaching [56].

\subsubsection{Emissions from Animals as Food Sources}

There are many tables that purport to measure the differences in the emissions generated by the rearing of different animals for human food. Caveats apply due to very high variability in emission intensity resulting from different practices and inputs to production around the world. The figures in Table 2 are a compilation from various sources.

Total emissions from global livestock represent about $14.5 \%$ of GHG emissions generated by human activity [70]. Fossil fuel claims about $20 \%$ of the sector's emissions. 
Table 2. GHG emissions for various food products and different studies. Variations within the same product category result from different farming methods, but also due to differences in LCA calculations. (Source: adapted from [67-69]).

\begin{tabular}{|c|c|c|}
\hline Product & $\mathrm{CO}_{2}$ (eq./kg) & Comments \\
\hline Beef & 44.8 & Mainly a result of methane and $\mathrm{N}_{2} \mathrm{O}$, not $\mathrm{CO}_{2}$ \\
\hline $\begin{array}{l}\text { Idaho and Nebraska beef } \\
\text { (average) }\end{array}$ & 33.50 & Farm-gate, quoted as $15.23 \mathrm{~kg}$ per pound of beef \\
\hline Idaho lamb & 44.96 & Farm-gate, average of low and high productivity \\
\hline Swedish pork & $3.3-4.4$ & \\
\hline Michigan pork & 10.16 & Farm-gate \\
\hline Farmed trout & 4.5 & Raised in ponds. Frozen, leaving retailer \\
\hline Cod & 3.2 & Frozen fillet, leaving retailer \\
\hline Chicken & 2.0 & (Round weight, US) \\
\hline Poultry (US) & 1.4 & \\
\hline Chicken & 4.6 & (Round weight, UK) \\
\hline $\begin{array}{l}\text { Farmed salmon } \\
\text { (sea-based, UK) }\end{array}$ & 3.6 & Including processing and transportation \\
\hline $\begin{array}{c}\text { Farmed salmon } \\
\text { (sea-based, Canada) }\end{array}$ & 4.2 & Adjusted to fillet based on figures for live fish \\
\hline $\begin{array}{c}\text { Farmed salmon } \\
\text { (sea-based, Norway) }\end{array}$ & 3.0 & Transportation to Paris \\
\hline $\begin{array}{l}\text { Farmed salmon } \\
\text { (global average) }\end{array}$ & 2.15 & Farm-gate estimates \\
\hline $\begin{array}{c}\text { Capture fish } \\
\text { (global average) }\end{array}$ & 1.7 & \\
\hline
\end{tabular}

\subsubsection{Genomics Has Revolutionised Dairy Farming}

Genomic evaluation estimates the genetic merit of an animal based on the DNA information. Its value depends on the traits of greatest utility, e.g., fat content, protein content [71]. Identifying superior animals at a much earlier age has obvious economic advantages [72]. A study overwhelmingly demonstrated improvement in significant traits after genomic selection was introduced [73].

Regarding sustainability, dairy farms are a significant source of greenhouse gas (GHG) emissions [74]. In 2015, dairy made up some $3.4 \%$ of global $\mathrm{CO}_{2}$ emissions, close to the contribution of aviation and shipping combined (https:/ /www.bbc.com/future/article/2 0201208-climate-change-can-dairy-farming-become-sustainable (accessed on 8 December 2021)). Genomic techniques have reduced environmental impacts along the production chain [75].

Nonetheless, challenges to further integration remain. For example, vigilance is needed to prevent inbreeding [76]. Perhaps the bigger challenges are not technical. Incentivising the collection of new phenotypes is a major challenge if the producer cannot recover the investment costs for these new technologies [77].

\subsubsection{Reducing Methane Emissions from Cows}

Not long after the threat of methane emissions from ruminants was highlighted [78], genetic selection was proposed as a mitigation solution. Through genomic selection, it is possible to decrease the methane production from cows [79]. However, there is a classic unintended consequences dilemma in using genomics to reduce $\mathrm{CH}_{4}$ emissions from cows: $\mathrm{CH}_{4}$ production is related to milk production [80], highlighting that apparently simple solutions have to be thoroughly investigated. 


\subsubsection{Aquaculture and the UN SDGs}

Aquaculture may come to the rescue of the world's over-fished wild fisheries. Fish farming now accounts for some $50 \%$ of total fish consumption. Fish and seafood consumption may rise by $27 \%$ by 2030 , mostly sustained by aquaculture [81]. Aquaculture is also associated with lower GHG emissions than other forms of farmed meat [82]. Consequentially, farmed fish aligns with more than one SDG, but there are consequences in others [83].

Farmed fish are susceptible to many infectious diseases: as much as $10 \%$ of all cultured aquatic animals are lost to infectious diseases, with an annual loss to the industry of over USD 10 billion [84]. Excessive use of antibiotics is thought to contribute to the spread of drug-resistant pathogens in wild fish. Worryingly, there seems to be a correlation between multiple antibiotic resistance in aquaculture-related bacteria with those in human clinical bacteria. This, say Reverter et al., implicates aquaculture in climate change and antimicrobial resistance [85].

Vaccination provides an alternative to antibiotics. The Norwegian salmon industry has all but eliminated antibiotics from production. Conventional vaccine production technology has been the norm for fish vaccines. Like with human vaccines, fish vaccines may be amenable to biotechnology and synthetic biology approaches $[86,87]$.

\subsection{Decontaminating the Bioeconomy}

\subsubsection{Biological Wastewater Treatment}

Wastewater management will need to play a central role in achieving future water security [88]. However, vast quantities of sewage and industrial wastes are still discharged untreated to fresh water bodies. With over a century of experience with biological treatment of wastewater, large problems could be addressed simply with greater implementation of current biological wastewater treatment technologies [89].

However, wastewater biorefining would add value. For example, a pilot-scale biorefinery has been operated at the Brussels North Wastewater Treatment Plant to evaluate PHA production [90].

Aerobic biological wastewater treatment needs large quantities of energy to comply with environmental regulations. In the United States, this amounts to over $20 \%$ of the public energy use of a municipality [91,92]. For example, the aeration of the activated sludge process can account for around $50-70 \%$ of the treatment plant energy costs [93].

Energy recovery in wastewater treatment plants could improve their energy efficiency [94]. One biotechnology solution may be microbial fuel cells (MFCs), microbial devices that generate electricity while breaking down organic material [95]. Despite intense research, technical difficulties remain, such as poor electron transfer between the microbial cells and the anode. This is another frontier for synthetic biology $[96,97]$.

\subsubsection{Bioremediation of Contaminated Land and Water}

One of the greatest conundrums of environment policy concerns soil. Soil produces $95 \%$ of human food, be it crops or the grasses and other plants used to feed animals for meat [98]. Yet, soil is ludicrously undervalued, and very little progress has been made in valuing the ecosystem services provided by soils $[99,100]$. Soil captures some $20 \%$ of human $\mathrm{CO}_{2}$ emissions, but is very easily damaged, and very slow to renew [101]. Contamination of soil through industrial activities is extremely widespread. In Europe alone, there are around 342,000 sites identified as contaminated [102].

A variety of physical, chemical and thermal technologies are available for the remediation of contaminated soils. In doing so, most of these technologies destroy or damage the soil. Bioremediation is a more sustainable technology, and may even improve soil quality $[103,104]$. However, barriers remain that limit its use in full-scale remediation projects that mostly relate to a lack of process control due to a lack of reliability and predictability [105]. Diplock et al. highlighted the urgent need for devices and software to demonstrate the genuine scientific basis that underpins the bioremediation process, and 
to improve the predictability of the process as an industrial practice [106]. The arrival of genomics and the most modern tools of biotechnology are starting to answer that need.

Metagenomics is the sequence of a complete environmental sample, not of a single pure species. It provides information on the microbial community composition based on the gene sequences present in a given sample. Although metagenomic sequencing can define the microbial and/or gene composition, it does not reveal details on the actual microbial activity responsible for active bioremediation processes. In this regard, community metaproteomics provides the most direct snapshot of microbial activity at the time of sampling and the best evidence available of active bioremediation. It is not yet ready for routine use, relying as it does on mass spectrometry [107]. In addition, modern technologies such as CRISPR will provide opportunities for the engineering of non-model bioremediation organisms [108].

\subsection{Curing in the Bioeconomy}

"Human health and well-being" is the title of SDG 3, and medicine is the heartland of biotechnology companies, having the most scientific advances and the clearest pipeline from research to application. Biopharmaceuticals comprise about $40 \%$ of pharmaceuticals in clinical development globally [109]. Several of the platforms, such as cell and gene therapies and -omics technologies, are addressing diseases with unmet needs. The biopharmaceuticals industry is considered to be on the cusp of an era of disease cure rather than treating symptoms [110]. Market size estimates vary but all predict a high compound annual growth rate (CAGR) over the next few years. Zhang and Liu have gone as far as to suggest that the biopharmaceuticals industry will become the world's largest industry, largely driven by an ageing population [111]. For the period 2030 to 2040, the direct economic potential of the sector could be USD 0.5 to 1.2 trillion [26].

Nucleic acid therapies are a pertinent case. They have a promising future in various healthcare areas [112]. In particular, mRNA therapeutics hold the promise of personalised cancer treatments [113]. There are many areas of human medicine where synthetic biology will have impact, a topic reviewed recently by Tew [114].

RNA Vaccines: From Scepticism to Fanfare in a Matter of Months

The vaccines industry has been beleaguered for decades, and the technology has changed only in detail. The nub of the problem is relatively poor profitability and the high production and R\&D costs [115]. For example, when huge numbers of eggs are needed, the process is expensive and laborious, but replacing them has proven difficult [116].

A bio-designed mRNA sequence is specifically designed for production of the exact antigens against the target virus. This has advantages; in particular, possessing the viral genome enables the direct design of an RNA vaccine [86]. As the need to handle live virus is removed, the mRNA vaccine production facilities can be greatly simplified, and made much smaller and less expensive, allowing production in many more locations, and potentially close to the point-of-care, such as in a hospital laboratory. Before the COVID-19 pandemic there were doubts regarding the efficacy of mRNA vaccines. Within a matter of a few months from the onset of the pandemic, at least two of these vaccines (Moderna and BioNtech) are actually in use with demonstrably very high efficacy.

\subsection{Securing the Bioeconomy}

An expansion of the bioeconomy also creates greater opportunities for crime. Biomass is already traded internationally and increasing demands for sustainability of biomass means that stakeholders such as port authorities will need improved technologies for monitoring and vigilance. In addition, as digital biology advances, there will be more opportunities for malicious cyberattacks on bio-based production companies. Biotechnologies have some of the answers. 


\subsubsection{Illegal Logging}

There are many negative economic, environmental and social consequences of illegal logging, up to and including violence and warlordism [117]. Deforestation accounts for around $17 \%$ of all anthropomorphic emissions. Between 15 and 30\% of wood traded globally is obtained illegally, rising to $50-90 \%$ in key tropical countries, making deforestation very difficult to control [118]. It can be highly selective, often involving endangered and expensive species. Illegal laundered timber is exported, often to the United States and Europe, further complicating traceability [119].

Wood species identification based on anatomical features alone is not always possible. It is possible to identify some woods from closely related species using DNA barcoding $[120,121]$. This can be done routinely, more quickly and with higher taxonomic resolution than by morphology methods [122]. This is one of the most promising tools for forensic forestry [123].

\subsubsection{Illegal Fishing, and Fish and Seafood Fraud}

Seafood is one of the most traded food commodities in the world. Some $90 \%$ of global fisheries are at or beyond their sustainable capacity [124]. Illegal, unreported and unregulated (IUU) fishing is one of the greatest threats to the sustainability of global fishery resources [125]. Large amounts of fresh/frozen finfish imports are in the form of products such as fillets and fish sticks, rendering visual traceability and species authentication impossible. Species substitution can be used for tax evasion, for laundering illegally caught fish or for substituting for species of higher value [126]. Traceability is becoming increasingly urgent.

DNA barcodes facilitate numerous related applications [127]. These include traceability, and monitoring illegal fishing and fish fraud [128,129]. Non-experts can sample highly processed material at low cost and with little effort. Combined with a universally accessible species identification database, this addresses difficulties in species authentication [130].

\subsubsection{Cyberbiosecurity, an Emerging Threat}

There are various stages in bioproduction susceptible to cyberattack, representing a "new threat landscape" [131,132], elevating cybersecurity to a "strategic imperative" for some companies [133]. Blockchain technology may have some of the answers. It can securely trace transactions between two parties. Public policy measures for cybersecurity include voluntary standards, regulations and information-sharing frameworks [134].

\subsection{Storing the Bioeconomy}

Since 2010, global internet traffic has grown 12-fold [135], increasing the electricity needs of the ICT sector. Already, ICT data centres use as much electricity as some countries [136]. By 2040, storing all data for instant access would exceed the availability of microchip-grade silicon by 10-100-fold [137]. A data crunch seems unavoidable without a radical solution.

The data storage potential of DNA (Figure 5) is much greater than all other media. The entire world's data may be storable in $1 \mathrm{~kg}$ of DNA [138]. Another estimate proposes that 215 petabytes ( 215 million gigabytes) - roughly all the information on the Internetcould be stored in one gram of DNA [139]. Moreover, DNA storage would be a low maintenance and low energy system [140]. Far-fetched as it may seem, this technology is already becoming available. Although currently expensive, it is likely that costs will drop as the customer base and capacity increases [141]. 


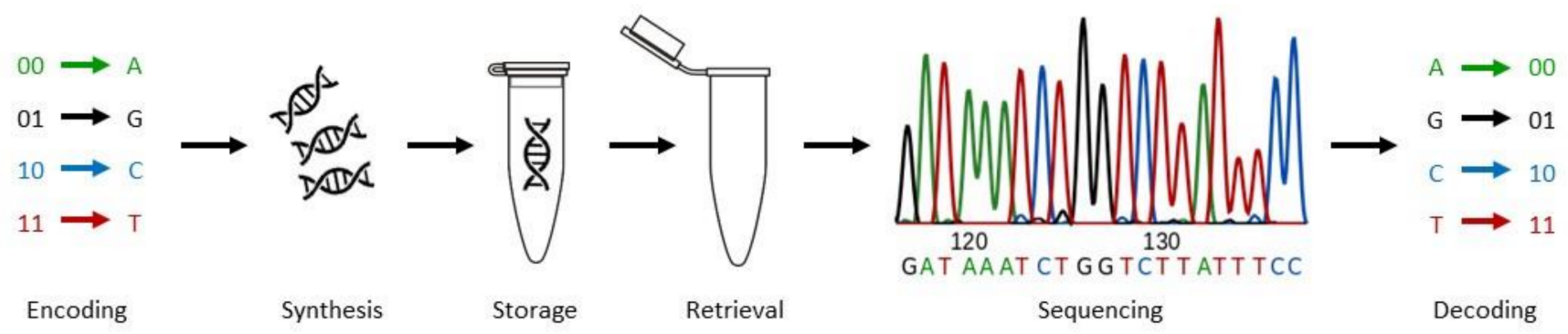

Figure 5. Information storage using DNA. Adapted from https://www.twistbioscience.com/products/storage (accessed on 8 December 2021).

\section{Conclusions}

The paper does not offer biotechnology and synthetic biology as the panacea for sustainability. There is no single science or technology breakthrough to solve all of the grand challenge problems that climate change brings to the surface [11]. What it does suggest is that the whole suite of technologies that come under the umbrella of biotechnology has been under-researched and de-emphasised in the global enterprise that constitutes the search for carbon neutrality.

Another aspect of biology and biotechnology is that the complexity of life offers huge flexibility in addressing these challenges. What is being faced can be regarded as a "grand challenges ecosystem"; making a change somewhere has consequences elsewhere. Chemical technology fixes have the inherent danger of being one dimensional. Synthetic biology can offer a variety of fixes in a single technology, such as drought and heat tolerance and pest resistance in a single plant species. A bacterium that degrades pollutants in a wastewater treatment plant in future might also generate electricity, or synthesise a biodegradable plastic. A yeast that can biodegrade a lignocellulosic feedstock and make a valuable chemical would simplify the production bioprocess. Many such examples can be imagined and many are as yet unforeseen. It is hard to imagine any other technology that would have this flexibility.

Policymakers must face this future prepared to make trade-offs while making best efforts to identify and model unintended (and unwanted) consequences. Another factor that policymakers are currently facing, and will face in the future, is public acceptance of biotechnology. According to the McKinsey Global Institute, up to $70 \%$ of the potential of the "Bio Revolution" may depend on consumer, societal and regulatory acceptance [26].

Funding: This research received no external funding.

Institutional Review Board Statement: Not applicable.

Informed Consent Statement: Not applicable.

Data Availability Statement: Not applicable.

Conflicts of Interest: The author declares no conflict of interest.

Disclaimer Statement: The views expressed are those of the authors and not necessarily those of the OECD or of the governments of its member countries.

\section{References}

1. OECD. The Bioeconomy to 2030: Designing a Policy Agenda. Available online: https://www.oecd.org/futures/long-termtechno logicalsocietalchallenges/thebioeconomyto2030designingapolicyagenda.htm (accessed on 21 April 2021).

2. Sverko Grdic, Z.; Krstinic Nizic, M.; Rudan, E. Circular Economy Concept in the Context of Economic Development in EU Countries. Sustainability 2020, 12, 3060. [CrossRef]

3. Stegmann, P.; Londo, M.; Junginger, M. The circular bioeconomy: Its elements and role in European bioeconomy clusters. Resour. Conserv. Recycl. 2020, 6, 100029. [CrossRef]

4. Birch, K.; Levidow, L.; Papaioannou, T. Sustainable Capital? The Neoliberalization of Nature and Knowledge in the European “Knowledge-based Bio-economy". Sustainability 2010, 2, 2898-2918. [CrossRef] 
5. George, G.; Howard-Grenville, J.; Joshi, A.; Tihanyi, L. Understanding and tackling societal grand challenges through management research. Acad. Manag. J. 2016, 59, 1880-1895. [CrossRef]

6. d'Hondt, K.; Jiménez-Sánchez, G.; Philp, J. Reconciling food and industrial needs for an Asian bioeconomy: The enabling power of genomics and biotechnology. Asian Biotechnol. Dev. Rev. 2015, 17, 85-130.

7. Frisvold, G.B.; Moss, S.M.; Hodgson, A.; Maxon, M.E. Understanding the U.S. Bioeconomy: A New Definition and Landscape. Sustainability 2021, 13, 1627. [CrossRef]

8. Bracco, S.; Calicioglu, O.; Gomez San Juan, M.; Flammini, A. Assessing the Contribution of Bioeconomy to the Total Economy: A Review of National Frameworks. Sustainability 2018, 10, 1698. [CrossRef]

9. Bugge, M.M.; Hansen, T.; Klitkou, A. What Is the Bioeconomy? A Review of the Literature. Sustainability $2016,8,691$. [CrossRef]

10. Vivien, F.-D.; Nieddu, M.; Befort, N.; Debref, R.; Giampietro, M. The hijacking of the bioeconomy. Ecol. Econ. 2019, 159, 189-197. [CrossRef]

11. Gates, B. How to Avoid a Climate Disaster: The Solutions We Have and the Breakthroughs We Need; Allen Lane: London, UK, $2021 ;$ p. 8.

12. Marvik, O.J.; Philp, J.; The Systemic Challenge of the Bioeconomy: A Policy Framework for Transitioning towards a Sustainable Carbon Cycle Economy. EMBO Reports. Available online: https://www.embopress.org/doi/full/10.15252/embr.202051478 (accessed on 21 April 2021).

13. McKinsey \& Company. Biotech in Europe: A Strong Foundation for Growth And innovation. Available online: https:/ / www.mckinsey.com/industries / pharmaceuticals-and-medical-products/our-insights/biotech-in-europe-a-stro ng-foundation-for-growth-and-innovation\# (accessed on 21 April 2021).

14. European Commission. Strengthening the Connection between Economy, Society and the Environment; European Commission (EC): Brussels, Belgium, 2018.

15. BIT II Bioeconomy in Italy. A New Bioeconomy Strategy for a Sustainable Italy. Available online: https:// knowledge4policy.ec. europa.eu/publication/bit-ii-bioeconomy-italy-new-bioeconomy-strategy-sustainable-italy_en (accessed on 21 April 2021).

16. Ministry of Agriculture and Food in France. A Bioeconomy Strategy for France. 2018-2020 Action Plan. Available online: https:/ / www.gouvernement.fr/sites/default/files/locale/piece-jointe/2018/10/france-bioeconomy_plan.pdf (accessed on 21 April 2021).

17. Bio-Strategy 2020 (Basic Measures). Available online: https://www.dwih-tokyo.org/files/2020/10/bio2020_honbun_en_rev-1.p df (accessed on 21 April 2021).

18. HM Government. Growing the Bioeconomy. Improving Lives and Strengthening Our Economy: A National Bioeconomy Strategy to 2030. Available online: https:/ / assets.publishing.service.gov.uk/government/uploads/system/uploads/attachment_data/fil e/761856/181205_BEIS_Growing_the_Bioeconomy_Web_SP_pdf (accessed on 21 April 2021).

19. National Academies of Sciences, Engineering, and Medicine. Safeguarding the Bioeconomy. Available online: https://www.nap. edu/catalog/25525/safeguarding-the-bioeconomy (accessed on 21 April 2021).

20. German Federal Government. National Bioeconomy Strategy Summary. Available online: https://www.bmbf.de/files/2020_15 01_National-Bioeconomy-Strategy_Summary_accessible.pdf (accessed on 21 April 2021).

21. High-Tech Forum. Bio IT Innovations. Convergence of Biosciences and Information Technologies. Available online: https: //www.hightech-forum.de/wp-content/uploads/htf_discussion_paper_bio_it_innovations.pdf (accessed on 21 April 2021).

22. Statista. Total Number of Biotechnology Firms in Selected European Countries in 2018. Available online: https:/ / www.statista.c om/statistics / 439960 / number-of-biotechnology-companies-europe-eu/ (accessed on 28 February 2021).

23. Schieb, P.-A.; Philp, J. Biorefinery policy needs to come of age. Trends Biotechnol. 2014, 32, 496-500. [CrossRef]

24. Carlson, R. Estimating the biotech sector's contribution to the US economy. Nat. Biotechnol. 2016, 34, 247-255. [CrossRef]

25. Ronzon, T.; Piotrowski, S.; Tamosiunas, S.; Dammer, L.; Carus, M.; M'barek, R. Developments of Economic Growth and Employment in Bioeconomy Sectors across the EU. Sustainability 2020, 12, 4507. [CrossRef]

26. McKinsey Global Institute. The Bio Revolution: Innovations Transforming Economies, Societies, and Our Lives. Available online: https:/ / www.mckinsey.com/industries/pharmaceuticals-and-medical-products/our-insights/the-bio-revolution-inn ovations-transforming-economies-societies-and-our-lives (accessed on 21 April 2021).

27. Bioindustrial Innovation. Canada's Bioeconomy Strategy: Leveraging our Strengths for a Sustainable Future. Available online: http:/ / www.biotech.ca/wp-content/uploads/2016/03/National_Bioeconomy_Strategy_EN-compressed.pdf (accessed on 28 February 2021).

28. French, K.E. Harnessing synthetic biology for sustainable development. Nat. Sustain. 2019, 2, 250-252. [CrossRef]

29. Lewin, H.A.; Robinson, G.E.; Kress, W.J.; Baker, W.J.; Coddington, J.; Crandall, K.A.; Durbin, R. Earth BioGenome Project: Sequencing life for the future of life. Proc. Natl. Acad. Sci. USA 2018, 115, 4325-4333. [CrossRef] [PubMed]

30. Frost, J.W.; Lievense, J. Prospects for Biocatalytic Synthesis of Aromatics in the 21st Century. New J. Chem. 1994, 18, 341-348.

31. Wong, K.-C. Computational Biology and Bioinformatics: Gene Regulation, 1st ed.; CRC Press: Boca Raton, FL, USA, 2016; pp. 154-196.

32. Yim, H.; Haselbeck, R.; Niu, W.; Pujol-Baxley, C.; Burgard, A.; Boldt, J.; Khandurina, J.; Trawick, J.D.; Osterhout, R.E.; Stephen, R.; et al. Metabolic engineering of Escherichia coli for direct production of 1,4-butanediol. Nat. Chem. Biol. 2011, 7, 445-452. [CrossRef] [PubMed]

33. OECD. Meeting Policy Challenges for a Sustainable Bioeconomy. Available online: https://www.oecd.org/publications/policy-c hallenges-facing-a-sustainable-bioeconomy-9789264292345-en.htm (accessed on 21 April 2021). 
34. Casini, A.; Chang, F.-Y.; Eluere, R.; King, A.M.; Young, E.M.; Dudley, Q.M.; Karim, A.; Pratt, K.; Bristol, C.; Forget, A.; et al. A pressure test to make 10 molecules in 90 days: External evaluation of methods to engineer biology. J. Am. Chem. Soc. 2018, 140, 4302-4316. [CrossRef]

35. Robinson, C.J.; Carbonell, P.; Jervis, A.J.; Yan, C.; Hollywood, K.A.; Dunstan, M.S.; Currin, A.; Swainston, K.J.; Spiess, N.; Taylor, R.; et al. Rapid prototyping of microbial production strains for the biomanufacture of potential materials monomers. Metab. Eng. 2020, 60, 168-182. [CrossRef] [PubMed]

36. Kitney, R.; Adeogun, M.; Fujishima, Y.; Goñi-Moreno, Á.; Johnson, R.; Maxon, M.; Steedman, S.; Ward, S.; Winickoff, D.; Philp, J. Enabling the advanced bioeconomy with engineering biology. Trends Biotechnol. 2019, 37, 917-920. [CrossRef]

37. Whitehead, T.A.; Banta, S.; Bentley, W.E.; Betenbaugh, M.J.; Chan, C.; Clark, D.S.; Hoesli, C.A.; Jewett, M.C.; Junker, B.; Koffas, M.; et al. The importance and future of biochemical engineering. Biotechnol. Bioeng. 2020, 117, 2305-2318. [CrossRef]

38. Coley, C.W.; Thomas, D.A., III; Lummiss, J.A.M.; Jaworski, J.N.; Breen, C.P.; Hart, V.T.; Fishman, J.S.; Rogers, L.; Gao, H.; Hicklin, R.W.; et al. A robotic platform for flow synthesis of organic compounds informed by AI planning. Science $2019,365$. [CrossRef] [PubMed]

39. Carbonell, P.; Le Feuvre, R.; Takano, E.; Scrutton, N.S. In silico design and automated learning to boost next-generation smart biomanufacturing. Synth. Biol. 2020, 5, ysaa020. [CrossRef] [PubMed]

40. Weiss, M.; Haufe, J.; Carus, M.; Brandão, M.; Bringezu, M.S.; Hermann, B.; Patel, M.K. A review of the environmental impacts of bio-based materials. J. Ind. Ecol. 2012, 16, 169-181. [CrossRef]

41. van Dam, J.; Junginger, M. Striving to further harmonization of sustainability criteria for bioenergy in Europe: Recommendations from a stakeholder questionnaire. Energy Policy 2011, 39, 4051-4066. [CrossRef]

42. Liew, F.; Martin, M.E.; Tappel, R.C.; Heijstra, B.D.; Mihalcea, C.; Köpke, M. Gas fermentation-A flexible platform for commercial scale production of low-carbon-fuels and chemicals from waste and renewable feedstocks. Front. Microbiol. 2016, 7, 694. [CrossRef]

43. WO/2020/186173. Gas Fermentation for the Production of Protein-Based Bioplastics. Available online: https://patentscope.wi po.int/search/en/detail.jsf?docId=WO2020186173 (accessed on 21 April 2021).

44. Pikaar, I.; Matassa, S.; Bodirsky, B.L.; Weindl, I.; Humpenöder, F.; Rabaey, K.; Boon, N.; Bruschi, M.; Yuan, Z.; van Zanten, H.; et al. Decoupling livestock from land use through industrial feed production pathways. Environ. Sci. Technol. 2018, 52, 7351-7359. [CrossRef] [PubMed]

45. Heijstra, B.D.; Leang, C.; Juminaga, A. Gas fermentation: Cellular engineering possibilities and scale up. Microb. Cell Factories 2017, 16, 60. [CrossRef] [PubMed]

46. Zhu, Q. Developments on $\mathrm{CO}_{2}$-utilization technologies. Clean Energy 2019, 3, 85-100. [CrossRef]

47. Handler, R.M.; Shonnard, D.R.; Griffing, E.M.; Lai, A.; Palou-Rivera, I. Life Cycle Assessments of ethanol production via gas fermentation: Anticipated greenhouse gas emissions for cellulosic and waste gas feedstocks. Ind. Eng. Chem. Res. 2016, 55, 3253-3261. [CrossRef]

48. Searchinger, T.; Heimlich, R.; Houghton, R.A.; Dong, F.; Elobeid, A.; Fabiosa, J.; Tokgoz, S.; Hayes, D.; Yu, T.-H. Use of US croplands for biofuels increases greenhouse gases through emissions from land-use change. Science 2008, 319, 1238-1240. [CrossRef] [PubMed]

49. Haberl, H. Competition for land: A sociometabolic perspective. Ecol. Econ. 2015, 119, 424-431. [CrossRef]

50. OECD. Realising the Circular Bioeconomy; OECD Publishing: Paris, France, 2017. Available online: https://www.oecd.org/officiald ocuments / publicdisplaydocumentpdf/?cote=DSTI/STP/BNCT(2017)7/FINAL\&docLanguage=En (accessed on 21 April 2021).

51. Cook, B.I.; Ault, T.R.; Smerdon, J.E. Unprecedented 21st century drought risk in the American Southwest and Central Plains. Sci. Adv. 2015, 1, e1400082. [CrossRef] [PubMed]

52. Karlen, D.L.; Rice, C.W. Soil Degradation: Will Humankind Ever Learn? Sustainability 2015, 7, 12490-12501. [CrossRef]

53. Bosch, R.; van de Pol, M.; Philp, J. Define biomass sustainability. Nature 2015, 523, 526-527. [CrossRef] [PubMed]

54. Sophocleous, M. Global and regional water availability and demand: Prospects for the future. Nat. Resour. Res. 2004, 13, 61-75. [CrossRef]

55. Hatfield, J.L.; Dold, C. Water-use efficiency: Advances and challenges in a changing climate. Front. Plant Sci. 2019, 10, 103. [CrossRef] [PubMed]

56. D'Hondt, K.; Kostic, T.; McDowell, R.; Eudes, F.; Singh, B.K.; Sarkar, S.; Markakis, M.; Schelkle, B.; Maguin, E.; Sessitsch, A. Microbiome innovations for a sustainable future. Nat. Microbiol. 2021, 6, 138-142. [CrossRef] [PubMed]

57. Tripathi, L.; Atkinson, H.; Roderick, H.; Kubiriba, J.; Tripathi, J.N. Genetically engineered bananas resistant to Xanthomonas wilt disease and nematodes. Food Energy Secur. 2017, 6, 37-47. [CrossRef] [PubMed]

58. Conrow, J.; GMO Banana Offers Hope for Disease and Pest Resistance. Cornell Alliance for Science. Available online: https:/ / allianceforscience.cornell.edu/blog/2017/04/gmo-banana-offers-hope-for-disease-and-pest-resistance/\#: \{\}: text=Share,a\%20newly\%20published\%20scientific\%20paper (accessed on 19 February 2021).

59. Singh, R.; Ong-Abdullah, M.; Low, E.-T.L.; Manaf, M.A.A.; Rosli, R.; Nookiah, R. Oil palm genome sequence reveals divergence of inter-fertile species in old and new worlds. Nature 2013, 500, 335-339. [CrossRef] [PubMed]

60. Cold Spring Harbor Laboratory News. Full Genome Map of Oil Palm Indicates A Way to Raise Yields and Protect Rainforest. Available online: http:/ / www.cshl.edu/News-Features/full-genome-map-of-oil-palm-indicates-a-way-to-raise-yields-and-p rotect-rainforest.html (accessed on 19 February 2021). 
61. Bloch, S.E.; Ryu, M.-H.; Ozaydin, B.; Broglie, R. Harnessing atmospheric nitrogen for cereal crop production. Curr. Opin. Biotechnol. 2020, 62, 181-188. [CrossRef] [PubMed]

62. Wang, W.; Pan, Q.; He, F.; Akhunova, A.; Chao, S.; Trick, H.; Akhunov, E. Transgenerational CRISPR-Cas9 activity facilitates multiplex gene editing in allopolyploid wheat. CRISPR J. 2018, 1, 65-74. [CrossRef] [PubMed]

63. Licht, S.; Cui, B.; Wang, B.; Li, F.-F.; Lau, J.; Liu, S. Ammonia synthesis by $\mathrm{N}_{2}$ and steam electrolysis in molten hydroxide suspensions of nanoscale $\mathrm{Fe}_{2} \mathrm{O}_{3}$. Science 2014, 345, 637-640. [CrossRef] [PubMed]

64. Rosenblueth, M.; Ormeño-Orrillo, E.; López-López, A.; Rogel, M.A.; Reyes-Hernández, B.J.; Martínez-Romero, J.C.; Reddy, P.M.; Martínez-Romero, E. Nitrogen fixation in cereals. Front. Microbiol. 2018, 9, 1794. [CrossRef] [PubMed]

65. Keasling, J. Building an opportunity space for synthetic biology. Int. Innov. 2015, 185, 24-25.

66. Stokstad, E. The nitrogen fix. Science 2016, 353, 1225-1227. [CrossRef] [PubMed]

67. Ellingsen, H.; Olaussen, J.O.; Utne, I.B. Environmental analysis of the Norwegian fishery and aquaculture industry-A preliminary study focusing on farmed salmon. Mar. Policy 2009, 33, 479-488. [CrossRef]

68. Pelletier, N.; Tyedmers, P.; Sonesson, U.; Scholz, A.; Ziegler, F.; Flysjo, A.; Kruse, S.; Cancino, B.; Silverman, H. Not all salmon are created equal: Life cycle assessment (LCA) of global salmon farming systems. Environ. Sci. Technol. 2009, 43, 8730-8736. [CrossRef] [PubMed]

69. Hamerschlag, K.; Venkat, K.; Environmental Working Group. Meat Eaters Guide to Climate Change and Health: Life Cycle Assessments Methodology and Results. Available online: http://static.ewg.org/reports/2011/meateaters/pdf/methodology_e wg_meat_eaters_guide_to_health_and_climate_2011.pdf (accessed on 20 February 2021).

70. Grossi, G.; Goglio, P.; Vitali, A.; Williams, A.G. Livestock and climate change: Impact of livestock on climate and mitigation strategies. Anim. Front. 2019, 9, 69-76. [CrossRef]

71. Agriculture and Horticulture Development Board. Factsheet. Genomics in the Dairy Industry. Available online: https://ahdb.org .uk/knowledge-library/genomics-in-the-dairy-industry (accessed on 14 February 2021).

72. Schefers, J.M.; Weigel, K.A. Genomic selection in dairy cattle: Integration of DNA testing into breeding programs. Anim. Front. 2012, 2, 4-9. [CrossRef]

73. Garcia-Ruiz, A.; Cole, J.B.; VanRaden, P.M.; Wiggans, G.R.; Ruiz-Lopez, F.J.; Van Tassell, C.P. Changes in genetic selection differentials and generation intervals in US Holstein dairy cattle as a result of genomic selection. Proc. Natl. Acad. Sci. USA 2016, 113, E3995-E4004. [CrossRef] [PubMed]

74. Rotz, C.A. Modeling greenhouse gas emissions from dairy farms. J. Dairy Sci. 2018, 101, 6675-6690. [CrossRef] [PubMed]

75. Capper, J.L.; Cady, R.A. The effects of improved performance in the U.S. dairy cattle industry on environmental impacts between 2007 and 2017. J. Anim. Sci. 2019, 98, skz291. [CrossRef] [PubMed]

76. Doublet, A.-C.; Croiseau, P.; Fritz, S.; Michenet, A.; Hozé, C.; Danchin-Burge, C.; Laloë, D.; and Restoux, G. The impact of genomic selection on genetic diversity and genetic gain in three French dairy cattle breeds. Genet. Sel. Evol. 2019, 51, 52. [CrossRef] [PubMed]

77. Cole, J.B.; Eaglen, S.A.E.; Maltecca, C.; Mulder, H.A.; Pryce, J.E. The future of phenomics in dairy cattle breeding. Anim. Front. 2020, 10, 37-44. [CrossRef] [PubMed]

78. Steinfeld, H.; Gerber, P.; Wassenaar, T.; Castel, V.; Rosales, M.; de Haan, C. Livestock's Long Shadow: Environmental Issues and Options. Available online: http:/ /www.fao.org/3/a0701e/a0701e00.htm (accessed on 21 April 2021).

79. de Haas, Y.; Windig, J.J.; Calus, M.P.L.; Dijkstra, J.; de Haan, M.; Bannink, A.; Veerkamp, R.F. Genetic parameters for predicted methane production and potential for reducing enteric emissions through genomic selection. J. Dairy Sci. 2011, 94, 6122-6134. [CrossRef] [PubMed]

80. Lassen, J.; Difford, G.F. Review: Genetic and genomic selection as a methane mitigation strategy in dairy cattle. Animal 2020, 14, s473-s483. [CrossRef] [PubMed]

81. World Bank. Fish to 2030: Prospects for Fisheries and Aquaculture. Agriculture and Environmental Services Discussion Paper. Available online: https:/ / openknowledge.worldbank.org/handle/10986/17579 (accessed on 21 April 2021).

82. MacLeod, M.J.; Hasan, M.R.; Robb, D.H.; Mamun-Ur-Rashid, M. Quantifying greenhouse gas emissions from global aquaculture. Sci. Rep. 2020, 10, 11679. [CrossRef]

83. FAO. The State of World Fisheries and Aquaculture 2018-Meeting the Sustainable Development Goals. Available online: http:/ / www.fao.org/3/i9540en/i9540en.pdf (accessed on 21 April 2021).

84. Figueroa, C.; Veloso, P.; Espin, L.; Dixon, B.; Torrealba, D.; Elalfy, I.S.; Afonso, J.M.; Soto, C.; Conejeros, P.; Gallardo, J.A. Host genetic variation explains reduced protection of commercial vaccines against Piscirickettsia salmonis in Atlantic salmon. Sci. Rep. 2020, 10, 18252. [CrossRef] [PubMed]

85. Reverter, M.; Sarter, S.; Caruso, D.; Avarre, J.-C.; Combe, M.; Pepey, E.; Pouyaud, L.; Vega-Heredía, S.; de Verdal, H.; Gozlan, R.E. Aquaculture at the crossroads of global warming and antimicrobial resistance. Nat. Commun. 2020, 11, 1870. [CrossRef] [PubMed]

86. Kitney, R.; Bell, J.; Philp, J. Build a sustainable vaccines industry with synthetic biology. Trends Biotechnol. 2021, in press. [CrossRef] [PubMed]

87. Ma, J.; Bruce, T.J.; Jones, E.M.; Cain, K.D. A review of fish vaccine development strategies: Conventional methods and modern biotechnological approaches. Microorganisms 2019, 7, 569. [CrossRef]

88. UN-Water. Wastewater Management-A UN-Water Analytical Brief. Available online: https://www.unwater.org/publications /wastewater-management-un-water-analytical-brief/ (accessed on 16 February 2021). 
89. El-Chichakli, B.; Von Braun, J.; Lang, C.; Barben, D.; Philp, J. Five cornerstones of a global bioeconomy. Nature 2016, 535, 221-223. [CrossRef] [PubMed]

90. Morgan-Sagastume, F.; Hjort, M.; Cirne, D.; Gérardin, F.; Lacroix, S.; Gaval, G.; Karabegovic, L.; Alexandersson, T.; Johansson, P.; Karlsson, A.; et al. Integrated production of polyhydroxyalkanoates (PHAs) with municipal wastewater and sludge treatment at pilot scale. Bioresour. Technol. 2015, 181, 78-89. [CrossRef] [PubMed]

91. Mo, W.; Zhang, Q. Energy-nutrients-water nexus: Integrated resource recovery in municipal wastewater treatment plants. J. Environ. Manag. 2013, 127, 255-267. [CrossRef] [PubMed]

92. US Department of Energy. The Water-Energy Nexus: Challenges and Opportunities. Available online: https://www.energy.gov / articles/water-energy-nexus-challenges-and-opportunities (accessed on 21 April 2021).

93. Energy Resources Center, University of Illinois. Wastewater Treatment Facilities Program-Reducing Energy Usage in Wastewater Treatment. Available online: http:/ / www.erc.uic.edu/energy-efficiency/illinois-energy-now-programs/waste-water-treatme nt-facilities-program (accessed on 21 April 2021).

94. Capodaglio, A.G.; Olsson, G. Energy Issues in Sustainable Urban Wastewater Management: Use, Demand Reduction and Recovery in the Urban Water Cycle. Sustainability 2020, 12, 266. [CrossRef]

95. Krieg, T.; Mayer, F.; Sell, D.; Holtmann, D. Insights into the applicability of microbial fuel cells in wastewater treatment plants for a sustainable generation of electricity. Environ. Technol. 2019, 40, 1101-1109. [CrossRef] [PubMed]

96. Li, F.; An, X.; Wu, D.; Xu, J.; Chen, Y.; Li, W.; Cao, Y.; Guo, X.; Lin, X.; Li, C.; et al. Engineering microbial consortia for high-performance cellulosic hydrolyzates-fed microbial fuel cells. Front. Microbiol. 2019, 10, 409. [CrossRef]

97. Zhang, T.; Ghosh, D.; Tremblay, P.-L. Synthetic Biology Strategies to Improve Electron Transfer Rate at the Microbe-Anode Interface in Microbial Fuel Cells, 1st ed.; Krishnaraj, R.N., Ed.; John Wiley and Sons: Hoboken, NJ, USA, 2019; pp. 187-208.

98. Ellis, H. Is the Source of 95 Percent of Our Food in Trouble? Available online: https://www.bbc.co.uk/food/articles/soil (accessed on 16 February 2021).

99. Baveye, P.C.; Baveye, J.; Gowdy, J. Soil "ecosystem" services and natural capital: Critical appraisal of research on uncertain ground. Front. Environ. Sci. 2016, 4, 41. [CrossRef]

100. D'Amato, D.; Bartkowski, B.; Droste, N. Reviewing the interface of bioeconomy and ecosystem service research. Ambio 2020, 49 , 1878-1896. [CrossRef] [PubMed]

101. European Commission. Environment Fact Sheet: Soil Protection-A New Policy for the EU. Available online: http:/ / ec.europa. eu/environment/pubs/pdf/factsheets/soil.pdf (accessed on 16 February 2021).

102. Panagos, P.; Van Liedekerke, M.; Yigini, Y.; Montanarella, L. Contaminated sites in Europe: Review of the current situation based on data collected through a European network. J. Environ. Public Health 2013, 2013, 158764. [CrossRef] [PubMed]

103. Sorvari, J.R.; Antikainen, R.; Kosola, M.L.; Hokkanen, P.; Haavisto, T. Eco- efficiency in contaminated land management in Finland-barriers and development needs. J. Environ. Manag. 2009, 90, 1715-1727. [CrossRef] [PubMed]

104. Shekhar, C. Nature cure: Bioremediation as a sustainable solution for polluted sites. Chem. Biol. 2012, 19, 307-308. [CrossRef]

105. Gillespie, I.M.M.; Philp, J.C. Bioremediation, an environmental remediation technology for the bioeconomy. Trends Biotechnol. 2013, 31, 329-332. [CrossRef] [PubMed]

106. Diplock, E.E.; Mardlin, D.P.; Killham, K.S.; Paton, G.I. Predicting bioremediation of hydrocarbons: Laboratory to field scale. Environ. Pollut. 2009, 157, 1831-1840. [CrossRef] [PubMed]

107. Abiraami, T.V.; Singh, S.; Nain, L. Soil metaproteomics as a tool for monitoring functional microbial communities: Promises and challenges. Rev. Environ. Sci. Bio/Technol. 2020, 19, 73-102. [CrossRef]

108. Liang, Y.; Jiao, S.; Wang, M.; Yu, H.; Shen, Z.A. CRISPR/Cas9-based genome editing system for Rhodococcus ruber TH. Metab. Eng. 2020, 57, 13-22. [CrossRef]

109. Walsh, G. Biopharmaceutical benchmarks 2018. Nat. Biotechnol. 2018, 36, 1136-1145. [CrossRef] [PubMed]

110. Deloitte Insights. The future of Biopharma. Reimagining Traditional Business Models in 2040. The Deloitte Center for Health Solutions. Available online: https:/ / www2.deloitte.com/cn/en/pages/life-sciences-and-healthcare/articles/the-future-of-bi opharma.html (accessed on 21 April 2021).

111. Zhang, K.; Liu, W. The current status, trend, and development strategies of Chinese biopharmaceutical industry with a challenging perspective. SAGE Open 2020, 10. [CrossRef]

112. Schlake, T.; Thran, M.; Fiedler, K.; Heidenreich, R.; Petsch, B.; Fotin-Mleczek, M. mRNA: A novel avenue to antibody therapy? Mol. Ther. 2019, 27, 773-784. [CrossRef] [PubMed]

113. Sahin, U.; Derhovanessian, E.; Miller, M.; Kloke, B.-P.; Simon, P.; Löwer, M.; Bukur, V.; Tadmor, A.D.; Luxemburger, U.; Schrörs, B.; et al. Personalized RNA mutanome vaccines mobilize poly-specific therapeutic immunity against cancer. Nature 2017, 547, 222-226. [CrossRef] [PubMed]

114. Tew, D. Synthetic biology and healthcare. Emerg. Top. Life Sci. 2019, 3, 659-667. [PubMed]

115. Nguyen, A.; Schwalbe, N. Apples and oranges? Can second generation vaccines become as low cost as generic medicines? Vaccine 2019, 37, 2910-2914. [CrossRef]

116. Trombetta, C.M.; Marchi, S.; Manini, I.; Lazzeri, G.; Montomoli, E. Challenges in the development of egg-independent vaccines for influenza. Expert Rev. Vaccines 2019, 18, 737-750. [CrossRef] [PubMed]

117. Reboredo, F. Socio-economic, environmental, and governance impacts of illegal logging. Environ. Syst. Decis. 2013, 33, 295-304. [CrossRef] 
118. Nellemann, C. INTERPOL Environmental Crime Programme. Green Carbon, Black Trade: Illegal Logging, Tax Fraud and Laundering in the Worlds Tropical Forests. A Rapid Response Assessment. United Nations Environment Programme. Available online: https:/ / wedocs.unep.org/20.500.11822/8030 (accessed on 10 December 2021).

119. Elliott, L. Transnational environmental crime in the Asia Pacific: An un(der)securitized security problem? Pac. Rev. 2007, 20, 499-522. [CrossRef]

120. Jiao, L.; Yin, Y.; Cheng, Y.-M.; Jiang, J.X. DNA barcoding for identification of the endangered species Aquilaria sinensis: Comparison of data from heated or aged wood samples. Holzforschung 2013, 68, 487-494. [CrossRef]

121. Kannangara, S.; Karunarathne, S.; Ranaweera, L.; Ananda, K.; Ranathunga, D.; Jayarathne, H.; Weebadde, C.; Sooriyapathirana, S. Assessment of the applicability of wood anatomy and DNA barcoding to detect the timber adulterations in Sri Lanka. Sci. Rep. 2020, 10, 4352. [CrossRef] [PubMed]

122. Fatima, T.; Srivastava, A.; Somashekar, P.V.; Hanur, V.S.; Rao, M.S. Development of DNA-based species identification and barcoding of three important timbers. Bull. Natl. Res. Cent. 2019, 43, 76. [CrossRef]

123. Jiao, L.; Lu, Y.; He, T.; Guo, J.; Yin, Y. DNA barcoding for wood identification: Global review of the last decade and future perspective. IAWA J. 2020, 41, 620-643. [CrossRef]

124. UNCTAD. $90 \%$ of Fish Stocks Are Used up-Fisheries Subsidies Must Stop. Available online: https://unctad.org/news/90-fishstocks-are-used-fisheries-subsidies-must-stop (accessed on 17 February 2021).

125. FAO. The State of World Fisheries and Aquaculture 2014 Highlights. Available online: http://www.fao.org/3/i3720e/i3720e.pdf (accessed on 21 April 2021).

126. Barendse, J.; Roel, A.; Longo, C.; Andriessen, L.; Webster, L.M.I.; Ogden, R.; Neat, F. DNA barcoding validates species labelling of certified seafood. Curr. Biol. 2019, 29, R198-R199. [CrossRef] [PubMed]

127. Ratnasingham, S.; Hebert, P.D.N. BOLD: The Barcode of Life Data System (www.barcodinglife.org). Mol. Ecol. Notes 2007, 7, 355-364. [CrossRef] [PubMed]

128. Costa, F.O.; Landi, M.; Martins, R.; Costa, M.H.; Costa, M.E.; Carneiro, M.; Alves, M.J.; Steinke, D.; Carvalho, G.R. A ranking system for reference libraries of DNA Barcodes: Application to marine fish species from Portugal. PLoS ONE 2012, 7, e35858. [CrossRef] [PubMed]

129. Bekkevold, D.; Helyar, S.; Limborg, M.; Nielsen, E.; Hemmer-Hansen, J.; Clausen, L.; Carvalho, G.R. Gene-associated markers can assign origin in a weakly structured fish, Atlantic herring. ICES J. Mar. Sci. 2015, 72, 1790-1801. [CrossRef]

130. Clark, L.F. The current status of DNA barcoding technology for species identification in fish value chains. Food Policy 2015, 54, 85-94. [CrossRef]

131. Peccoud, J.; Gallegos, J.E.; Murch, R.; Buchholz, W.G.; Raman, S. Cyberbiosecurity: From naive trust to risk awareness. Trends Biotechnol. 2018, 36, 4-7. [CrossRef] [PubMed]

132. Richardson, L.C.; Connell, N.D.; Lewis, S.M.; Pauwels, E.; Murch, R.S. Cyberbiosecurity: A call for cooperation in a new threat landscape. Front. Bioeng. Biotechnol. 2019, 7, 99. [CrossRef] [PubMed]

133. KPMG. Digitalization in Life Sciences. Available online: https://assets.kpmg/content/dam/kpmg/xx/pdf/2018/01/digitalizati on-in-life-sciences.pdf (accessed on 21 April 2021).

134. OECD. Chapter 6. Digitalisation in the Bioeconomy: Convergence for the Bio-Based Industries. Available online: https://www.oecd-ilibrary.org/sites/bd16d851-en/index.html?itemId=/content/component/bd16d851-en (accessed on 21 April 2021).

135. IEA. Data Centres and Data Transmission Networks. Available online: https://www.iea.org/reports/data-centres-and-data-tran smission-networks (accessed on 21 April 2021).

136. Jones, N. The information factories. Nature 2018, 561, 163-166. [CrossRef] [PubMed]

137. Zhirnov, V.; Zadegan, R.M.; Sandhu, G.S.; Church, G.M.; Hughes, W.L. Nucleic acid memory. Nat. Mater. 2016, 15, 366-370. [CrossRef] [PubMed]

138. Extance, A. How DNA could store all the world's data. Nature 2016, 537, 22-24. [CrossRef]

139. Service, R.F. DNA Could Store All of the world's Data in One Room. Available online: https://www.sciencemag.org/news/2017 /03/dna-could-store-all-worlds-data-one-room (accessed on 21 April 2021).

140. Goldman, N.; Bertone, P.; Chen, S.; Dessimoz, C.; LeProust, E.M.; Sipos, B.; Birney, E. Towards practical, high-capacity, lowmaintenance information storage in synthesized DNA. Nature 2013, 494, 77-80. [CrossRef] [PubMed]

141. Twist Bioscience. DNA-Based Digital Storage White Paper. Available online: https://www.twistbioscience.com/resources/whit e-paper/dna-based-digital-storage (accessed on 21 April 2021). 